The University of Akron

\title{
IdeaExchange@UAkron
}

Proceedings from the Document Academy

University of Akron Press Managed

December 2017

\section{Deconstructing the VISA: Academic Accommodations and Self-Disclosure}

Catherine A. Smith $\mathrm{PhD}$

University of Wisconsin-Madison, casmith24@wisc.edu

Please take a moment to share how this work helps you through this survey. Your feedback will be important as we plan further development of our repository.

Follow this and additional works at: https://ideaexchange.uakron.edu/docam

Part of the Health Information Technology Commons, and the Higher Education Commons

\section{Recommended Citation}

Smith, Catherine A. PhD (2017) "Deconstructing the VISA: Academic Accommodations and Self-Disclosure,"

Proceedings from the Document Academy: Vol. 4 : Iss. 2 , Article 13.

DOI: https://doi.org/10.35492/docam/4/2/13

Available at: https://ideaexchange.uakron.edu/docam/vol4/iss2/13

This Conference Proceeding is brought to you for free and open access by University of Akron Press Managed at IdeaExchange@UAkron, the institutional repository of The University of Akron in Akron, Ohio, USA. It has been accepted for inclusion in Proceedings from the Document Academy by an authorized administrator of

IdeaExchange@UAkron.For more information, please contact mjon@uakron.edu, uapress@uakron.edu. 


\section{Introduction}

Personal health records (PHRs), have been technically defined as "collections of health or wellness data arising from multiple sources about an individual's health managed, controlled or shared by that individual or designate." (Archer, FevrierThomas, Lokker, McKibbon, \& Straus, 2011, p. 515). The forms they take vary from simple apps to web-based journals to full-fledged patient portals, which allow the user to view lab results, document symptoms, and email physicians all from one convenient location. Paper-based personal health records have been a feature of different clinical specialties since the 1950s, when they were launched in a pilot study involving public health practitioners and migrant farm workers (Zusman, 1964) and their digital descendants are an emerging area of research interest today. There is little empirical evidence for positive clinical outcomes of PHR usage, but patient users still tend to be positive about increased access to information (Archer et al., 2011; Gysels, Richardson, \& Higginson, 2006).

Information and communication are intertwined; even a paper-based clinical documentation system can be a vehicle for information sharing. When considering health information sharing, a particular problem is posed by "fourth parties," people who handle clinical information but are neither health nor allied health professionals, nor patients, nor friends or family members of patients. This paper presents the results of a study assessing the attitudes and opinions about documentation of key "fourth parties" - the disability services staffers central to the academic accommodations process at two Midwestern universities. The goal of the whole project is to better understand the challenges of health information management among young adults negotiating higher education while managing health conditions.

\section{The academic accommodations process}

A single document with singular importance at the author's university is the VISA: "Verified Individualized Services and Accommodations." This single document simultaneously stands in for and attests to the existence and validity of multiple other documents produced by other writers at other times. The VISA is issued by the disability services center, carried as a laminated paper form by the client, and presented on paper to the client's instructors. By standing in for a mass of other documents, it attests that the client has a disability requiring academic accommodations. A digital VISA has the potential not only to open the doors of higher education, but to facilitate self-disclosure of disability on the part of the patient. But to understand how that might work, one has to understand the academic accommodations process in higher education. 
Table 1

Five most prevalent disabilities in postsecondary education

\begin{tabular}{|l|l|l|}
\hline & Overall & In 4-year colleges \\
\hline Disability type & & \\
\hline Learning disabilities & $62.5 \%$ & $21.2 \%$ \\
\hline Intellectual disability & $11.7 \%$ & $6.7 \%$ \\
\hline Emotional disturbance & $11.5 \%$ & $10.8 \%$ \\
\hline Other health impairment & $4.6 \%$ & $19.6 \%$ \\
\hline $\begin{array}{l}\text { Speech or language } \\
\text { impairments }\end{array}$ & $4.1 \%$ & $32.5 \%$ \\
\hline
\end{tabular}

*Source: Leake, 2015

The U.S. Department of Education's National Longitudinal Transition Study-2, or NLTS2, reports data that illustrates what disabilities can be encountered in postsecondary education. Disabilities can be cognitive, mental, or physical and the topography here is varied. The NLTS2 reports on young adults with disabilities who had been out of high school for up to eight years. There was a very good response rate $-82 \%$ at baseline and $72 \%$ in the final wave, conducted in 2008 . These are NLTS2's top 5 reported disabilities in descending order by prevalence- the first percentage is overall in the sample; the second percentage in brackets shows the percentage in 4-year-colleges specifically, the focus of the present study (Leake, 2015).

"Other health impairments" are "chronic or acute health problems that adversely affect educational performance. The most common are attention deficit disorders, with other examples including asthma, diabetes, epilepsy, and heart conditions." (Leake, 2015, p. 80).

It's important to understand that the transition to secondary education means a sea change in requirements for the student who is entering college with a disability. In elementary and secondary school, school staff develop Individual Education Plans, or IEPs, for the student; conversely, college and university educators receive communications from the campus disability services offices; and disability services staff mediate between student and instructor as a kind of honest broker; but the student herself steers the process (Gil, 2007).

And through this process, documentation is key. The accommodations process begins and ends with personal conversations initiated through, supported by, and productive of documentation: "[T]he DS staff will listen to what the student says and verify it with the third-party documentation of the disability. Using the documentation and the student's report, the staff member will make 
accommodation recommendations" which ideally allow the student to initiate conversations [with faculty] about their needs (Cory, 2011, p. 30).

Figure 1 below shows a VISA form in use at the University of Wisconsin-Madison. The form is, information-wise, almost the opposite of a clinical document. There is no statement of a diagnosis; the diagnosis itself is left up to the student client to disclose or not. Instead, what the VISA documents is the services and academic accommodations that the holder of this document is entitled to receive because of the diagnosis that the recipient of the document does not necessarily know. What complexities lie behind these simple checkboxes on this relatively simple form?

Figure 1

VISA form for documentation of academic accommodations

\begin{tabular}{|c|c|}
\hline $\begin{array}{l}\text { McBurney Center VISA } \\
\text { (Verified Individualized Services and Accommodations) }\end{array}$ & $\begin{array}{l}\text { Original VISA Date } \\
\text { Revised On }\end{array}$ \\
\hline Emaî: mcburney@studentlife.wisc.edu & Expiration \\
\hline $\begin{array}{l}\text { Voice (608) 263-2741 · Text (608) 225-7956 · Fax (608) 265-2998 } \\
\text { Student }\end{array}$ & $\begin{array}{l}\text { Recommended services are effective } \\
\text { through the above expiration date, } \\
\text { unless otherwise indicated by a duration }\end{array}$ \\
\hline Student's Email & \\
\hline
\end{tabular}

TO FACULTY: The UW-Madison McBurney Disability Resource Center recommends the following accommodations for this student. Recommendations are based upon disability documentation and an individualized assessment of the student's needs. Revisions occur with additional information, changes in disability status, or periodic review. Contact the student's Accommodations Specialist with questions regarding the provision of accommodations and services, or visit McBumey's website (uww.mcburney.wisc.edu/visa). Accommodation and disability information should be regarded as confidential information at all times.

Level I Instructional Services and Accommodations

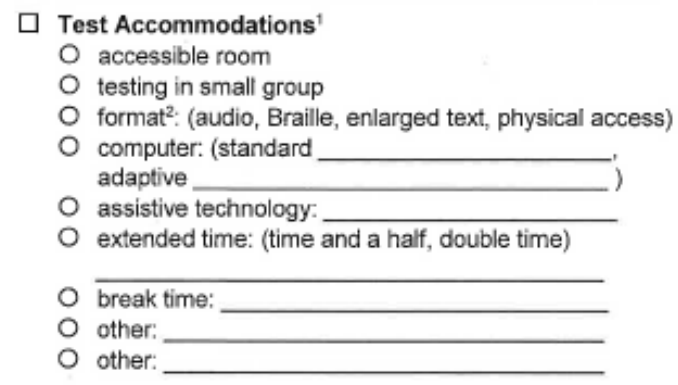

$\square$ Assistive Listening Device

$\square$ Media Captioning'

$\square$ Class Relocation

$\square$ Document Conversion ${ }^{1,2}$ : (audio, Braille, enlarged text, physical access)

$\square$ Laboratory Assistance:

$\square$ Notetaking': (paid notetaker, smartpen [I, II])

$\square$ Realtime Captioning ${ }^{1}$

$\square$ Seating: (furniture, preferential)

$\square$ Sign Language Interpreting ${ }^{1}$

$\square$ Other Level I:

$\square$ Other Level I:

\section{Methods}

The author and a doctoral student conducted 17 semistructured interviews with Disabilities Services (DS) staff between January and April, 2013. Institutional 
Review Board approval was obtained in February 2013 from Universities A (large research-intensive) and B (medium-sized master's-level) These two universities are of different sizes and engage mixes of students with different kinds of disabling conditions, thus ensuring some diversity in the data. While 17 people is a small number of people, these subjects included directors of both centers ( 2 women) and $100 \%$ of the 15 staff (13 women, 2 men) directly involved with all academic accommodations provided at these universities; these 15 staffers and 2 directors constitute the only federally mandated gateway to accommodations at their campuses. The combined total enrollments for those two institutions at the time of the study was 55,306; the most recent US department of education estimates for college students living with disabilities nationally was 11\%; (O’Neill, Markward \& French, 2012; National Center for Education Statistics, 2012); that would put the potential clientele for these two institutions at over 6,000 students for these 17 staffers.

Audio files were transcribed and coded using NVIVO 10 (QSR; www.qsrinternational.com).

\section{Results}

The documentation the interviewees reported was heavily dependent, of course, on the impairments experienced by the student clients with whom they interact. Interview subjects reported receiving documentation from a wide range of clinical specialties for diagnoses including neuropsychiatric, ENT, low vision, traumatic brain injury and autoimmune diseases.

Typical documentation includes psychoeducational evaluations (reported by $35 \%$ of subjects); audiograms, case notes, and letters from physicians (18\%); medical records, records of office visits, treatment and neuropsychiatric reports (12\%); and discharge summaries and psychiatric records $(<1 \%)$.

The condition of the documentation provided becomes a symptom of the issues the client brings with them. For example, sometimes students do not have all the records they require. One subject reported:

"Often for a student with learning disabilities, a student was identified as a child and has a long paper history that comes with them. Students with ADHD might not have been diagnosed maybe till high school, or college, or even as an adult-so getting enough documentation to even understand exactly how this diagnosis is impacting them can be a challenge and sometimes a student has been diagnosed by let's say a family doctor or a general practitioner who may not have expertise in ADHD, so the documentation I get from that person is very limited. So not getting 
enough or the quality of the documentation might not be there so that can be a challenge." [Subject A6]

Many of our interview subjects described problems caused by missing documentation. It has to be obtained by the student and it has to be supplied by the right kind of health professional.

"Documentation is always an issue, especially getting it from the provider. We really put that on the students. We let them know what they need to do to become a client of ours, and one of the things is documentation from their provider. And sometimes it's.. on the student, and they don't request it, they don't request it, they don't request it and we keep having to remind them. And then on the flip side, sometimes we see it on the provider side, where they're just not sending it, or they take a long time to send it." [Subject A5]

Even students who go through the process and are provided with VISAs continue to face obstacles. There is "presentational risk" involved in voluntarily placing oneself in a stigmatized group (Quinlan, Bates, \& Angell, 2012). Seventy-five percent of students in one study did not self-identify as disabled to their classmates, and $61 \%$ did not to professors. One quarter of these students were "fearful" about discussing accommodations with their professors (Baker, Boland \& Nowik, 2012). Disabilities services staff(Collins \& Mowbray, 2005) have identified "stigma" as "the biggest barrier for students to access [disability services]" (Kranke, Jackson, Taylor, Anderson-Fye \& Floersch, 2013).

One interview subject very eloquently expressed the equation some student clients make between possession of a VISA and possession of a stigmatizing identity:

"One student who just does not want to have a VISA. Does not, does not, does not, does not, does not. And his life would be so much easier. He has it, he signed it, he came in again. But I just got an email from faculty that he hasn't showed it to the faculty. But yet he said "Call McBurney". So I said yeah, I can vouch for the student, please, you know, if you can make that accommodation, these are accommodations that he's eligible for and it would make a big difference." [Subject A4]

One subject drew an explicit connection between documentation and visibility of the condition for which accommodations are needed:

"The more visible, obvious and stable the condition is, the less documentation they need. [T]he documentation helps us understand the individual person. The less 
visible the impairment is, the more variance it can have in the population of people who have that, and the more important the documentation is to that person." [Subject A1]

We have some understanding of the level of stigma at the national level. Researchers Newman and Madaus (2015) found that only 35\% of youth living with disabilities had informed their college of the disability; $95 \%$ had received accommodations at the secondary level but only $23 \%$ at the postsecondary level. Invisible disabilities in particular impose a self-stigma on the student' which is an additional block to achieving self-efficacy. $85 \%$ of college students registered with disability services in one study reported that their disability was invisible (Kranke et al., 2013). Jung (2002) specifies chronic illness, for example, relapsing/remitting autoimmune conditions, which are likely to be invisible conditions, as a problematic subtype within the "medical" category.

These disabilities have been associated with negative faculty attitudes - outright skepticism and distrust -affecting the provision of academic accommodations. "There's a lot of teachers that don't agree with this disability because they don't see it," said one student quoted in Kurth \& Mellard (2006). Not only do faculty seem to find it harder to work with invisible than visible disabilities, but these effects also are found when students disclose to other students. Jung (2002) suggests that this occurs because visible disabilities - mobility and apparent sensory impairments - provide in their very nature "incontrovertible proof", while invisible impairments are both more ambiguous and more difficult to substantiate.

When a gatekeeping document like the VISA has been obtained, the VISA itself becomes that incontrovertible proof. As Stein (2013) notes, accommodation cards, letters, and VISA or passport-like documents from Disability Services themselves are serving as a physical verification that a disability exists. As one subject quoted from one of her clients: "I can openly explain to teachers and have documentation, yes, I have a real disability and they can see that [italics mine]." Empowerment and self-advocacy is important because the fear of self-disclosure is considered a significant obstacle to academic accommodations and thus to academic success.

After briefly summarizing the definition and functions of typical PHRs, interview subjects were asked: "Do you think that a PHR might be useful in some way for students with disabilities?" This question was left purposely open-ended; some of our 14 subjects interpreted it from a student client's perspective, others spoke from their DS role.

Information management. Subject A6 commented on the ease of access for students if information is centralized: "When they need to access that 
information ... particularly for accommodations that might be a really convenient efficient way to get the information that we're requesting from there." Subject A2 also took the student's perspective: "I think it would be nice for our students ... to provide some documentation of their cases. Sometimes we will request documentation from a doctor... and then you'll just get all the case notes, which can be really difficult to read ... you have to spend time to figure it out. ... [F]or our students to use that and access that instead of the documentation, [i]t opens up a door: "Oh, I took this off MyChart".

Communication. Subjects A2 and B7 believed PHRs could facilitate dialogue between DS staff and client: "If a student called up his PHR and said "I would like to share this. Could you put something down about the impact of my condition, and my academics" ... that would be really helpful. I think there's a definitely a space for it to help in my position, for sure." [Subject A2] DS staff state that their own access to comprehensive information helps them understand the student client's "story". For example, Subject A9 reported that one student client composed her own clinical timeline: "I had an unusual client the other day ... the student actually took the time to outline in chronological order what's been happening with her, because it was kind of a new thing that she was experiencing ... [t] hat gave me a much clearer picture frankly than the big report that I got from her doctor that didn't give me that kind of information. ... I do absolutely think that if [a PHR] has that kind of information in it, strategies that they've used that have been successful ... that would be very helpful."

Advocacy. Subject B2 saw a role for PHRs in facilitating a student's own management of her health information to enable her to self-advocate: "I think a student probably should learn, while they're still in high school, to take more responsibility for managing, dealing ... to take on responsibility for [managing their health information]."

Complexity of information. Subject B3 felt that a PHR would be helpful because of his particular student population. However, he ascribed the usefulness to the complexity of his clients' situations. He made a direct correlation between health information complexity and utility of PHRs: "[A PHR] would be really, really helpful...some of my students who are medically fragile go to their doctors more frequently than all my other co-workers' students do ... a lot of times I'll get a summary, or the last eval, but I don't know about the 15 surgeries they had between birth and 10. .....My co-workers that I work with [might have] a file folder."

DS staff see the potential of the PHR not only for information management, but for communication about information being managed. These professionals educate student clients about advocacy; and they perceive that when technology enables these clients to "tell their own story", technology is empowering. The perspective 
of "fourth parties" on the difficulties of information management and sharing is unique. Thus these staffers are in a unique position to facilitate student access to education; neither administrators nor professors, not family members, not caregivers, but mediators between the student and the learning environment. Consumer health information technologies - including but not limited to PHRscould be a part of the solution.

\section{References}

Archer, N., Fevrier-Thomas, U., Lokker, C., McKibbon, K. A., \& Straus, S. E. (2011). Personal health records: a scoping review. Journal of the American Medical Informatics Association : JAMIA, 18(4), 515-522. http://doi.org/10.1136/amiajnl2011-000105.

Baker, K.Q., Boland, K., \& Nowik, C.M. (2012). A campus survey of faculty and student perceptions of persons with disabilities. Journal of Postsecondary Education and Disability, 25(4):309-329.

Collins, M.E., \& Mowbray, C.T. (2005). Higher education and psychiatric disabilities: National survey of campus disability services. American Journal of Orthopsychiatry, 75(2): 304-315.

Cory, R.C. (2011). Disability services offices for students with disabilities: A campus resource. New Directions in Higher Education, 154:27-36.

Gil, L.A. (2007). Bridging the transition gap from high school to college preparing students with disabilities for a successful postsecondary experience. Teaching Exceptional Children, 40(2):12-15.

Gysels, M., Richardson, A., \& Higginson, I.J. (2006). Does the patient-held record improve continuity and related outcomes in cancer care: a systematic review. Health Expectations, 10:75-91.

Jung, K.E. (2002). Chronic illness and educational equity: The politics of visibility. NWSA Journal, 14(3), 178-200.

Kranke, D., Jackson, S.E., Taylor, D.E., Anderson-Fye, E., \& Floersch, J. (2013). College student disclosure of non-apparent disabilities to receive classroom accommodations. Journal of Postsecondary Education and Disability, 26(1):35-51. 
Kurth, N., \& Mellard, N. (2006). Student perceptions of the accommodation process in postsecondary education. Journal of Postsecondary Education and Disability, 19(1): 71-84.

Leake, D. (2015). Problematic data on how many students in postsecondary education have a disability. Journal of Postsecondary Education and Disability, 28(1), 73-87.

National Center for Education Statistics, U.S. Department of Education (2012). Digest of Education Statistics, 2011 (2012-001).Available online: https://nces.ed.gov/fastfacts/display.asp?id=60. Date accessed: October 29, 2017.

Newman, L.A., \& Madaus, J.W. (2015). Reported accommodations and supports provided to secondary and postsecondary students with disabilities: National perspective. Career Development and Transition for Exceptional Individuals, 38(3): 173-181.

O’Neill, L.N.P., Markward, M.J., \& French, J.P. (2012). Predictors of graduation among college students with disabilities. Journal of Postsecondary Education and Disability, 25(1):21-36.

Quinlan, M.M., Bates, B.R., \& Angell, M.E. (2012). 'What can I do to help?' Postsecondary students with learning disabilities' perceptions of instructors' classroom accommodations. Journal of Research in Special Education Needs, 12(4):224-233.

Stein, K.F. (2013). DSS and accommodations in higher education: Perceptions of students with psychological disabilities. Journal of Postsecondary Education and Disability, 2, 145-161.

Zusman, J. (1964). A study of use of health records by 83 California families. American Journal of Public Health, 54(6): 908-917. 